\title{
PROTECTION OF SOCIO-ECONOMIC RIGHTS BY THE CONSTITUTIONAL COURT OF THE RUSSIAN FEDERATION
}

\author{
Svetlana Karamysheva* \\ Constitutional Court of the Russian Federation, Saint Petersburg, Russia \\ svetlana.karamysheva@ksrf.ru
}

Received: 4 July 2019 | Revised: 7 April 2020 | Accepted: 15 April 2020

\begin{abstract}
The article studies practice of the Constitutional Court of the Russian Federation in the field of socio-economic rights. The statistical data analysed illustrates the ever-present socio-economic theme among constitutional complaints lodged with the Constitutional Court, with the lowering of overall proportion of such complaints and increasing of the number of such complaints related to defence of property. Such statistics appear to be consistent with the Court's role in the ongoing transition from Soviet-style planned economy to free market, which implies a substantial shift of obligations connected with property management and social responsibilities from the State to citizens themselves. It follows from the Constitutional Court practice and doctrine that such shift should be done delicately, giving the citizens sufficient period of time to adapt to the changes. In the article, the author focuses on the following categories of complaints considered by the Constitutional Court of the Russian Federation: protection of the right to private property and protection of the right to pension provision. The author observes that the delicate balance that needs to be preserved when dealing with the cases of this type and the slow-pace nature of the transition process often results in criticism towards the Court, notwithstanding the rationale of its decisions. It follows that such criticism is somewhat natural; what matters is the Court's understanding of its mission in the socio-economic field, and maintaining balanced and well-reasoned approach in development of its case-law.
\end{abstract}

Keywords: Constitutional Court of the Russian Federation, Protection of Property, Social State, Socio-Economic Rights, State Responsibilities.

Counsellor at the Department of International Relations and Research of Constitutional Review Practice of the Constitutional Court of the Russian Federation, Saint Petersburg, Russia. 


\section{INTRODUCTION}

Probably every person on the planet dreams of not only eternal peace, but also of social justice to one degree or another, as well as of economic prosperity and stability. Socio-economic rights are the second generation rights and as such have special nature, the theoretical debate about which continues to this day. Without going into nuances, it can be said that their main difference from civil and political human rights is that their recognition, implementation and protection are possible only if they are recognized within society; from practical perspective we note the need for the state to participate in creating the conditions and mechanisms for ensuring them.

At the same time, the participation of the state, on the one hand, is a guarantee of the implementation and protection of the socio-economic rights of citizens, and on the other hand, a limiting factor for their realization, since both the economic freedom and opportunities of citizens largely depend on the economic policy of the state, and state social security always limited by budget, economic situation and other circumstances. That is why in different states at the constitutional level the issue of recognition and consolidation of this category of rights is decided differently.

In states where the possibility of judicial protection of this category of rights is legislatively fixed, as in the Russian Federation, the constitutional control body plays a special role. The Constitutional Court of the Russian Federation, which has broad competence in the field of constitutional control a posteriori and which jurisprudence consists primary of the so-called structural rulings, is trying to find a very fragile balance that allows on one side protecting constitutional human rights, and on the other, to not violate the principle of separation of powers and to not interfere in the political and economic sphere, which is the prerogative of the legislator.

In addition to eliminating obvious legislative defects and constitutional contradictions, as well as adjusting law enforcement practice, the Constitutional Court of the Russian Federation primarily establishes certain guidelines for the 
development of legislation in the socio-economic sphere, which is characterised by special responsibility and complexity. In its decisions and legal positions, the Constitutional Court, while exercising a stabilising function in matters of implementing the principle of a social state, takes into account the level of real economic opportunities of the country at the present stage of its development and proceeds from the need to find a balance of competing rights and interests so that "the social rights of citizens were properly protected and, at the same time, the ways for reforming, including in the area of social policy, were not closed."

The purpose of this article is to describe (the development over time) and analyze the legal positions of the Constitutional Court of the Russian Federation on the protection of socio-economic rights in order to identify the basic principles that guide the Constitutional Court in resolving this category of cases in order to achieve the mentioned balance.

Due to the limits of the paper, it is impossible to highlight all the legal positions of the Constitutional Court of the Russian Federation on the whole spectrum of socio-economic rights. However, I would like to dwell on the most relevant and from a today's perspective controversial, i.e. in the field of economic rights - to note certain points regarding the right to private property, and in the field of social rights - the right to pension provision.

The first part of the paper is devoted to the description of the situation with socio-economic rights in Russia, first of all, their legislative consolidation, the powers of the Constitutional Court of the Russian Federation, analysis of statistics on appeals to the Constitutional Court and its decisions. It also provides introductory general provisions and legal positions of the Constitutional Court of the Russian Federation in the socio-economic sphere.

The second part of the article analyzes the decisions of the Constitutional Court of the Russian Federation on the right to private property and slightly affects the relationship of the Constitutional Court of the Russian Federation

\footnotetext{
Valery Zorkin, "Pretsedentnyy kharakter resheniy Konstitutsionnogo Suda Rossiyskoy Federatsii [The Precedent Nature of Decisions of the Constitutional Court of the Russian Federation]," Zhurnal konstitutsionnogo prava, no. 12 (2004).
} 
with the European Court of Human Rights and the correlation of their legal positions.

The third part discusses the evolution of the legal positions of the Constitutional Court of the Russian Federation on the issue of pension provision for citizens, including one of the latest high-profile decisions regarding the current pension reform in Russia.

\section{SOCIO-ECONOMIC RIGHTS AND THE CONSTITUTIONAL COURTS OF THE RUSSIAN FEDERATION}

\subsection{Socio-Economic Rights in the Constitution of the Russian Federation}

The Constitution of the Russian Federation, ${ }^{2}$ adopted at a national referendum on 12 December 1993, became the Constitution of a new country. To mark the beginning of the transition to a new political system based on the rule of law and respect for rights and freedoms, the drafters of the 1993 Constitution took 3 important steps. Firstly, the list of rights and freedoms of a very protectionist nature (rather paternalistic) was reduced, it began to comply with international standards. New guarantees were also introduced to strengthen institutional systems, both federal and regional, aiming at protection and promotion of human rights, and preventing their violation. The third important breakthrough was the accession of Russia to international justice system, guaranteeing of its citizens with the constitutional right to appeal to international jurisdictions, when all domestic methods of protection have been exhausted. ${ }^{3}$ Presently the Russian Federation proclaims itself to be a social state whose policy is aimed at creating conditions ensuring a decent life and free development of man. The Constitution of the Russian Federation follows the Universal Declaration of Human Rights and the International Covenant on Economic, Social and Cultural Rights of 1966 and recognizes: the right to private property, the right to freedom of entrepreneurial and other economic activities (Articles 34, 35, 36), the

\footnotetext{
"Constitution of the Russian Federation - 1993," http://www.ksrf.ru/en/INFO/LEGALBASES/CONSTITUTIONRF/ Pages/default.aspx.

3 Colodrovschi Danelciuc, "Fédération de Russie [Russian Federation]" (Annuaire international de justice constitutionnelle [The international yearbook of the constitutional justice], 2014), 29-2013.
} 
right to work and protection of labour rights by all means provided for by law, including the right to strike, as well as the right to join trade unions (Article 37), the right to protection of the family, maternity and childhood (Article 38), the right to social security (Article 39), the right to housing (Article 40), the right to health and medical care (Article 41), the right to a favourable environment (Article 42), the right to education (Article 43), the right to freedom of literary, artistic and other forms of creativity (Article 44). Moreover, Article 17 of the Constitution of the Russian Federation establishes that fundamental human rights and freedoms are inalienable and belong to everyone from birth, and Article 2 establishes that the recognition, observance and protection of human and civil rights and freedoms is the duty of the state, without any division into types or categories of these rights. Therefore, the Russian Constitution can be reasonably called extremely "advanced" in the sense of recognising socio-economic human rights. Speaking of the constitutionalisation of social rights in the first place, theoretically, there are three groups of constitutions: ${ }^{4}$ constitutions which lack rules on social rights (these are primarily common law countries such as the USA, Canada, the UK); constitutions where social rights are enshrined indirectly through the main goals and principles of the state (for example, Germany, Spain, Malta, etc.); constitutions where social rights are directly enshrined and are subject to constitutional regulation. The Constitution of the Russian Federation thus belongs to the latter group, therefore, in Russia one can "consider social rights enshrined in the Constitution not only as guidelines for the legislator, but precisely as fundamental rights equal in importance to constitutional civil and political rights." 5

The problem of judicial protection of socio-economic rights arises with renewed vigor during difficult economic periods when along with a decrease in resources, the state's burden to fulfill its social obligations increases.

\footnotetext{
See e.g.: Natalya Kolotova, "Konstitutsionalizatsiya sotsial'nykh prav - tendentsiya razvitiya sovremennogo prava [Constitutionalization of Social Rights - a Trend in the Development of Modern Law]," Konstitutsionnoye i munitsipal'noye pravo [Constitutional and Municipal Law], no. 1 (2019): 5-9.

5 Valery Zorkin, "Sotsial'noye gosudarstvo v Rossii: problemy sotsializatsii [The Social State in Russia: Problems of Socialization]," Sravnitel'noye konstitutsionnoye obozreniye [Comparative Constitutional Review], no. 1 (2008): 49.
} 
The main issue when discussing socio-economic rights from an international law and a comparative law perspectives is the possibility of judicial protection of this group of rights, the justiciability, ${ }^{6}$ which includes the ability to have procedural remedies (access to independent and impartial justice), as well as the opportunity to obtain effective compensation for violation of rights. ${ }^{7}$

Article 46 of the Constitution of the Russian Federation establishes a guarantee of judicial protection of rights and freedoms for everyone, without differentiating the groups rights, which accordingly brings social rights under judicial protection and allows citizens of the Russian Federation, unlike many other countries, to have certain specific requirements in the socio-economic sphere, including, first and foremost, actively defend and protect them. The Constitutional Court of the Russian Federation ${ }^{8}$ (hereinafter also called- CC $\mathrm{RF}$ ), which is the body of constitutional review, independently exercising judicial power through judicial proceedings on the basis of the federal constitutional law of 21 July 1994 "On the Constitutional Court of the Russian Federation," 9 plays a huge role in the mechanism of judicial protection of social and economic rights. Analysing thematic statistics of complaints ${ }^{10}$ to the Constitutional Court of the Russian Federation, we can see that this method of protection is quite popular among citizens.

\subsection{Statistics of Complaints to the Constitutional Court of the Russian Federation}

Within the last years, the Constitutional Court of the Russian Federation receives 14-15 thousand constitutional appeals (complaints) annually. Moreover, the overwhelming majority thereof are complaints from citizens and their associations who exercise the right to file a constitutional complaint as enshrined

6 Dmitrii Kuznetcov, "Sudebnaya zashchita sotsial'no-ekonomicheskikh prav: Pro et Contra [Justiciability of Social and Economic Rights: Pro et Contra]," Vremya I Pravo [Time and Law], no. 4 (2014): 6.

7 "Courts and the Legal Enforcement of Economic, Social and Cultural Rights: Comparative Experiences of Justiciability," International Commission of Jurists, Geneva, 2008, 10.

8 See more at "Official Website of the Constitutional Court of the Russian Federation," http://www.ksrf.ru/EN/ INFO/Pages/default.aspx.

9 Federal Constitutional Law of July 21, 1994, No. 1-FCL, on Constitutional Court of the Russian Federation. http:// www.ksrf.ru/en/Info/LegalBases/FCL/Pages/default.aspx.

10 Such annual statistics have been maintained by the Secretariat of the Constitutional Court of the Russian Federation since 2003 . 
in Article 125 of the Constitution of the Russian Federation. The second place in the number of appeals belongs to general jurisdiction and arbitration courts, which can appeal to the Constitutional Court of the Russian Federation if, while considering a specific case, a court finds that the law applied or to be applied in this case is unconstitutional.

Since it is unreasonable and quite complicated to separate the number of complaints in respect of each social right, the paper represents the graph of the number of complaints on social protection issues (red line on the graph) as a percentage of the total number of appeals to the Constitutional Court of the Russian Federation by years. It makes possible to see how peak years for such complaints correlates with the implementation of state reforms in the social sphere, and to observe a downward trend and maintaining a stable percentage in the following years.

\section{Graphic 1}

Graph of the number of complaints for social protection as a percentage of the total number of complaints to the Constitutional Court of the Russian Federation

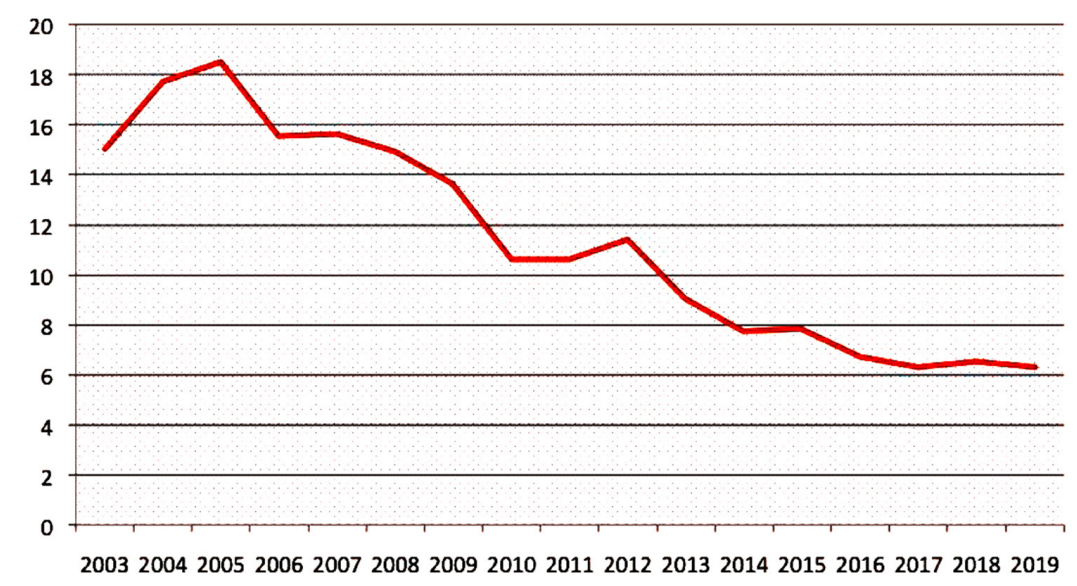

As regards the protection of economic rights, the number of such complaints to the Constitutional Court of the Russian Federation is much smaller, and the statistics have changed thematically. Hence, highlighting for example property 
rights complaints, the protection of which by the Constitutional Court of the Russian Federation will be considered in a detail below, until 2011 such appeals were counted in the section "Reform in the field of economics and finance: privatisation, ownership, entrepreneurial activity" (blue line on the graph), and since 2012 years - in the section "Civil law: property right and other property rights" (red line on the graph). The corresponding schedule is presented below:

\section{Graphic 2}

Graph of the number of complaints on the issues including property rights as a percentage of the total number of complaints to the Constitutional Court of the Russian Federation

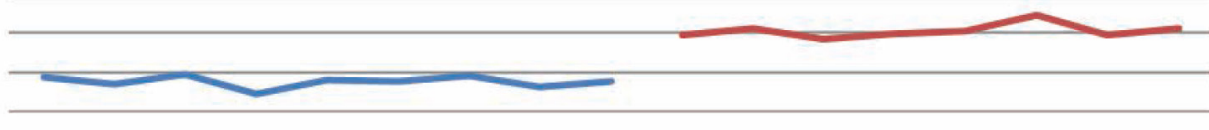

20032004200520062007200820092010201120122013201420152016201720182019

Thus, we can conclude that the number of such appeals never exceeded the 2.5 percent limit.

\subsection{Statistics of Decisions of the Constitutional Court of the Russian Federation}

Constitutional protection of socio-economic rights is carried out by the Constitutional Court of the Russian Federation by means of constitutional proceedings (consideration of a case to verify the constitutionality of a particular norm) both by holding a public hearing of the case and by applying the procedure without holding a public hearing (written proceedings) the result of which may be:

1. Adoption of the decision on the refusal to consider the case (hereinafter inadmissibility decision). This type of decisions of the Constitutional Court of the Russian Federation can in no case be excluded from the general defence mechanism, since such decisions, firstly, may contain significant legal positions of the Constitutional Court of the Russian Federation, and 
even recommendations addressed to the legislator, and secondly, may have purely practical value for the applicants and provide for the possibility of reviewing their cases.

2. Adoption of a decision with final Judgement (hereinafter - Judgement):

- on the recognition of the challenged norm to be in accordance with the Constitution of the Russian Federation (constitutional),

- on the recognition of a norm as being not in accordance with the Constitution of the Russian Federation (unconstitutional),

- on recognition of the norm to be in accordance with the Constitution of the Russian Federation in the revealed constitutional and legal sense, which is binding upon the decision.

Below are the statistics on decisions of the Constitutional Court of the Russian Federation in the socio-economic sphere."

\section{Table 1}

Statistics on Decisions of the Constitutional Court of the Russian Federation in the Socio-Economic Sphere

\begin{tabular}{|l|l|}
\hline Overall number of Judgements of the CC RF & 586 \\
\hline Among them regarding the issues of social protection and social security & 54 \\
\hline $\begin{array}{l}\text { Among them regarding the issues of property rights and other rights } \\
\text { in rem }\end{array}$ & 23 \\
\hline Overall number of inadmissibility decisions of the CC RF & 33869 \\
\hline Among them regarding the issues of social protection and social security & $\mathbf{2 8 2 2}$ \\
\hline $\begin{array}{l}\text { Among them regarding the issues of property rights and other rights } \\
\text { in rem }\end{array}$ & $\mathbf{1 5 3 3}$ \\
\hline
\end{tabular}

11 As to 1 July 2019 . 


\subsection{Substantive Aspect of the Decisions of the Constitutional Court of the Russian Federation}

The Constitutional Court of the Russian Federation believes that the protection of socio-economic rights is one of the most important of its tasks. Turning to the substantive aspect and the question of how to implement constitutional legal protection of socio-economic rights, I would like to quote judge of the Constitutional Court of the Russian Federation N.S. Bondar, who names the following methods of constitutionalisation of social protection institutions (this classification can be equally applied to the economic sphere): constitutional interpretation of the legal norms of certain branches of social legislation (pension, housing, family, social security law, labour law, etc.); constitutional adjustment of prevailing law enforcement practice, which gave or may give an unconstitutional meaning to the provisions of social legislation; identification of the constitutional nature of the social rights of citizens, giving them qualities of natural, inalienable and basic; interpretation of the norms of the Constitution itself, with the help of which a constitutional assessment and justification of sectorial social legislation is ensured and, at the same time, the development of the content of the constitutional norms themselves without changing the text of the corresponding constitutional provisions on social protection. ${ }^{12}$

A very important aspect in respect of socio-economic rights protection is the issue of methodology. In continental (European) legal systems, although they do not directly apply the political question doctrine, it distinguishes between "legal analysis" and "analysis of opportunities and beliefs," include consideration of political issues. However, there are no clear criteria which would make this or that issue purely technical or political, therefore,

12 Nikolai Bondar, "Zashchita sotsial'no-ekonomicheskikh prav konstitutsionnymi sudami stran Vostochnoy Yevropy. Rossiyskaya Federatsiya. Konstitutsionnoye pravosudiye i sotsial'noye gosudarstvo [Protection of Socio-Economic Rights by the Constitutional Courts of Eastern Europe. Russian Federation. Constitutional Justice and Welfare State]" (M. Institut prava i publichnoy politiki, 2003), 172.

${ }^{13}$ Ceia Eleonora Mesquita,"The applicability of the political question doctrine in the foreign affairs field: should international treaties be regarded as non-justiciable acts?" (Paper presented at the IACL 2007 World Congress, Athens, June 2007). 
the border between the problems that are subject to constitutional review is very flexible and variable. ${ }^{14}$

On the issues of the permissibility of restricting the rights and freedoms of man and citizen, the Constitutional Court of the Russian Federation has repeatedly noted that these restrictions must be proportionate to constitutionally recognized goals and at the same time, the essence and the real content of the law itself (for example, Judgements of 19 July 2011 No. 17-P and 22 April 2013 No. 8-P). The constitutional grounds for such an interpretation of the criteria for limiting human rights were the provisions of Section 2 of Article 55 of the Constitution of the Russian Federation, which contains a ban on the derogation of the rights and freedoms of man and citizen, as well as Section 3 of Article 55 that human rights can be limited only to the extent necessary in order to protect constitutional values.

The Constitutional Court of the Russian Federation has also repeatedly emphasized that maintaining citizens' trust in the law and actions of the state presupposes legal certainty, maintaining a reasonable stability of legal regulation, the inadmissibility of arbitrary changes to the current system of norms and the predictability of legislative policy so that participants in the relevant legal relations can reasonably foresee consequences of their behaviour and to be sure of the immutability of their officially recognized status, acquired rights, the effectiveness of state protection, i.e., that the right acquired by them on the basis of the current legislation will be respected by the authorities and will be implemented (Judgements of 16 December 1997 No. 20-P, 24 May 2001 No. 8-P, 19 June 2002 No. 11-P, 23 April 2004 No. 9-P, Decision of 4 December 2003 No. 415-O, etc.).

The Constitutional Court of the Russian Federation also noted that in the field of social security, adherence to the principle of equality means inter alia the prohibition of introducing differences in the rights of persons belonging to the same category without objective and reasonable justification (prohibition of

${ }_{14}$ See e.g.: Diane A. Desierto, "Justiciability of Socio-Economic Rights: Comparative Powers, Roles, and Practices in the Philippines and South Africa," Asian-Pacific Law \& Policy Journal 11, no. 1 (2009). 
different treatment of persons in the same or similar situations) (e.g. Judgement of 16 July 2007 No. 12-P), and differences in the conditions for the acquisition by certain categories of citizens of social rights and its implementation are permissible if they are objectively justified and pursue a constitutionally significant aims, are used to achieve these objectives, and the legal means are proportionate thereto (e.g. Judgment of 15 March 2005 No. 3-P).

The indicated legal positions of the Constitutional Court of the Russian Federation can be called fundamental in the protection of socio-economic rights. In protection of the Court's approach, I would like to bring some arguments empirically extracted from the Court's case law. Firstly, the possibility of constitutional courts to consider issues relating to civil and political rights is not in doubt, because in this case the courts are not included in the assessment of the economic situation or in the redistribution of resources, which traditionally falls under the competence of political branches of government. Secondly, when discussing approximate content of socio-economic rights, it is not taken into account that human rights are an extremely broad category. Each right has its own content, which is established in the framework of international treaties, constitutional law-making, interpretation of rights by courts and other bodies, including supranational ones. ${ }^{15}$ Thirdly, the Constitutional Court is not willing to make a strict division between positive and negative rights in respect of the second generation rights. ${ }^{16}$ Although it goes without saying that in implementing socio-economic rights, the state often needs to spend more resources than in the case of first-generation rights, however, this is rather a matter of quantity than quality, which does not affect the essence of rights. ${ }^{17}$ And finally, the problem of the extent of judicial intervention in the sphere of realisation of socio-economic rights shall be considered from the point of view of admissibility, degree and possibility of influence on democratically elected bodies from the

15 See Sandra Liebenberg, Social and Economic Rights in Constitutional Law of South Africa 41-11 (M. Chaskalson et al (eds.)) (Cape Town: Juta, 1996).

16 For a details in a comparative perspective see: Henry Shue, Chapters 1-2 of Basic Rights: Subsistence, Affluence, and U.S. Foreign Policy (Princeton University Press, 1980).

17 Philip Alston and Gerard Quinn, "The Nature and Scope of States Parties' Obligations under the International Covenant on Economic, Social and Cultural Rights," Human Rights Quarterly 9, no.2 (May 1987): 156-229. 
side constitutional justice. Without going into theoretical details regarding the relationship between the political branches of government and the judiciary, it should be noted that the democratic legitimacy of constitutional review of the observance of socio-economic rights follows from the need to protect and ensure the interests of minorities or groups of people whose interests are not represented and not protected. ${ }^{18}$

\section{PROTECTION OF THE RIGHT TO PRIVATE PROPERTY IN THE LEGAL POSITIONS OF THE CONSTITUTIONAL COURT OF THE RUSSIAN FEDERATION}

First of all, it should be noted that in the USSR there was virtually no private property right, and since the establishment of the Constitutional Court of the Russian Federation in 1991, the latter has been at the forefront of the political and economic transformations that have taken place in the society. As noted by the President of the Constitutional Court of the Russian Federation V.D. Zorkin, "the constitutionally enshrined right of private property and the right to entrepreneurial activity were truly a stunning novelty for the majority of Russian citizens. The novelty with which the citizens came across for the first time in their lives and with which they simply did not understand what to do. And since the developed legislative framework for the realisation of these rights at the time of the adoption of the new Constitution was practically absent, and even later lagged behind the requirements of legal regulation of relations in the sphere of property and entrepreneurship, the process of realising these rights in Russia has been accompanied by gross and minor violations for many years." ${ }^{19}$

Correcting the legislative and law enforcement practice at that time, the Constitutional Court of the Russian Federation made a great contribution to the establishment and strengthening of the concept of private property law, its

\footnotetext{
18 See e.g.: Aoife Nolan, Bruce Porter, Malcolm Langford, "The Justiciability of Social and economic Rights: an Updated Appraisal" (CHRGJ Working Paper No. 15, 2007).

19 Valery Zorkin, "Rossiya: dvizheniye k pravu ili khaosu. Sotsial'no-gosudarstvennyy krizis i pravovaya sistema [Russia: Movement towards Law or Chaos. Social and State Crisis and Legal System]", http://www.patriarchia. ru/db/text/209611.html [last access: 8 August 2019].
} 
borders and its implementation in the period of the transition from Soviet-style planned economy to free market.

According to Article 35 of the Constitution of the Russian Federation, the right to private property is protected by law (Section 1); everyone has the right to own property, to use it and dispose of it both individually and jointly with other persons (Section 2); no one may be deprived of his property except by a court decision, and the compulsory alienation of property for State needs can be made only on condition of preliminary and equivalent compensation (Section 3).

In the Judgement of 17 December 1996 No. 20-P the Constitutional Court of the Russian Federation established that the right to private property is not absolute and does not belong to such rights that, in accordance with Article 56 (Section 3) of the Constitution of the Russian Federation, are not subject to any restriction. Therefore, within the meaning of Article 55 (Section 3) of the Constitution of the Russian Federation, the right in question can be limited by a federal law, but only to the extent necessary to protect the foundations of the constitutional order, morality, health, rights and legitimate interests of others, and ensure defence of the country and state security. This corresponds to the universally recognized principles and norms of international law, in particular the Universal Declaration of Human Rights of 10 December 1948, according to which everyone has obligations to a society in which the free and full development of his personality is possible (Part 1 of Article 29); in the exercise of their rights and freedoms, each person shall be subject only to such restrictions which are established by law solely to ensure due recognition and respect for the rights and freedoms of others and to satisfy the fair requirements of morality, public order and general welfare in a democratic society (Part 2 of Article 29). A similar provision on the permissibility of restricting human and civil rights is also provided for by the International Covenant on Economic, Social and Cultural Rights of 19 December 1966 (Article 4).

In the said case, the Constitutional Court of the Russian Federation considered the constitutionality of certain provisions of the law of the Russian Federation "On Federal Bodies of the Tax Police" and came to the conclusion 
that the collection of tax cannot be regarded as arbitrary deprivation of an owner of his property - it represents a legitimate seizure of part of the property arising from the constitutional public law obligation.

The Judgement of the Constitutional Court of the Russian Federation dated 20 May 1997 No. 8-P examined the norms of the Customs Code stipulating the right of customs authorities to carry out, along with other types of penalties, confiscation of goods and vehicles as objects of violation of customs rules. The Constitutional Court of the Russian Federation indicated that if a person does not agree with the seizure of property in the form of an administrative decision on confiscation, he has the opportunity to challenge the correctness of the decision in a court; the possibility of appealing decisions and actions of state authorities and their officials to a court is a general guarantee arising from Article 46 (Section 2) of the Constitution of the Russian Federation.

For persons who violate customs laws and for whom the competent state authorities apply sanctions for the offense, the right to use the constitutional guarantee to protect private property through the court is retained, but this protection will take place on the basis of subsequent judicial control. Thus, the Constitutional Court of the Russian Federation established that the issuance by customs authorities of a confiscation of property in the form of a sanction for a customs offense with a guarantee of subsequent judicial control as a way of protecting the rights of the owner does not contradict the requirements of the Constitution of the Russian Federation.

In the Judgement of 11 March 1998 No. 8-P the Constitutional Court of the Russian Federation recognized the norms of the RSFSR Code of Administrative Offenses and the Customs Code of the Russian Federation, on the basis of which citizens were deprived of their property without a court decision and without the possibility of appealing against the said actions in a court of law - contrary to Article 35 (Section 3) of the Constitution of the Russian Federation and its judicial guarantees of property rights, which correspond to the norms of international law, providing, in particular, the right of everyone in determining his rights and obligations in any civil proceedings to a fair and 
public hearing by a competent, independent and impartial tribunal established by law (Article 14 of the International Covenant on Civil and Political Rights of 19 December 1966).

This legal position was developed in later decisions of the Constitutional Court of the Russian Federation, for example, in the Judgement of 16 July 2008 No. 16-P:

The constitutional guarantees of the protection of private property rights by law and the permissibility of deprivation of property, only by a court decision, expressing the principle of inviolability of property, and constitutional guarantees of judicial protection extend both to the sphere of civil law relations and to relations between the state and the individual in the public law sphere. This means that in cases of seizure of property from the owner, regardless of the grounds for such seizure (including to ensure criminal proceedings), since it is mandatory and involves a dispute about the right to this property, an effective judicial procedure must be carried out.

The seizure of property from the owner or legal owner is permissible without a court decision only in cases where such a seizure is a procedural measure of an interim nature and is temporary, does not lead to the deprivation of a person's right of ownership and involves subsequent judicial control; the alienation of property seized as evidence in a criminal case is impossible without a court decision.

By virtue of the fundamental principles of the rule of law and legal equality, state interference in property relations (and the Constitutional Court of the Russian Federation has repeatedly called attention to it in its decisions) is permissible only if it is not arbitrary and does not upset the balance between the requirements of the interests of society and the necessary conditions for protecting fundamental rights of the individual, suggest a reasonable proportionality of the means used and the aim pursued, thus, a balance is ensured between constitutionally protected values and provides that a person is not subjected to excessive burden. ${ }^{20}$

20 See Valery Zorkin, Axiological Aspects of the Russian Constitution. Chapter in Constitutional Topography Vol.6 (Eleven International Publishing. 2010); Thomas Kleinlein, "The Procedural Approach in International Human Rights Law and Fundamental Values: Towards a Proceduralization of the Interface of International and Domestic Law?" (European Society of International Law (ESIL) 2017 Annual Conference (Naples) (April 15, 2018)). 
Hence, by the Judgement of 14 June 2015 No. 13-P the contested provisions of the Federal Law "On State Registration of Rights to Real Estate and Transactions Therewith" were recognized as not complying with the Constitution of the Russian Federation to the extent that they did not allow payment to a bona fide purchaser, from whom housing was sought, one-time compensation at the expense of the treasury of the Russian Federation in cases where, for reasons beyond the control of it, in accordance with a court decision that entered into legal force to compensate him for harm caused as a result of the loss of such property, recovery under an executive document within one year from the day the calculation deadline for presenting this document for execution was not carried out on the grounds of the lack of grounds for holding the competent state body responsible for illegal actions (inaction) associated with the state registration of rights to the indicated premises.

One more case can be noted regarding the rights of a bona fide purchaser and the actions of state bodies. In the Judgement of 22 June 2017 No. 16-P the Constitutional Court of the Russian Federation recognized the disputed provision of the Civil Code of the Russian Federation inconsistent with the Constitution of the Russian Federation to the extent that it permits the recovery from unlawful possession of residential premises, which had been escheated, from its bona fide purchaser, who, on a chargeable purchase of this dwelling, relied on the data of the Unified State Register of Real Estate and, in the manner prescribed by law, registered the ownership of it, by and appropriate public law body in the case when this public law body has not taken - in accordance with the requirements of reasonableness and prudence in the control of escheated property - timely measures to establish it and properly register the ownership of this property.

In this case, the Constitutional Court of the Russian Federation agreed with the position of the European Court of Human Rights, according to which the claim for housing on the claim of a public law body, subject to repeated verification by the public authorities themselves during administrative procedures for registering property rights with title documents and transactions concluded in relation to the relevant object, entails disproportionate interference with the 
exercise of the right of ownership of housing, if public authorities know about the status of the dwelling as an heirless property, but failed to take timely action to obtain title and protection of their rights thereto.

\section{3bis. Private Property Rights by Constitutional Court of the Russian Federation and by European Court of Human Rights}

Russia is a party to the Convention for the Protection of Human rights and Fundamental Freedoms. ${ }^{21}$ Hence, Russia has recognized jurisdiction of the European Court of Human Rights (hereinafter - the ECtHR) whose decisions and legal positions constitute a part of Russian legal system.22

Until recently, it seemed that on the issue of relationship between Russia's Constitution and the Convention there was absolutely no serious theoretical problem. After all, both the Constitution and the Convention quite clearly "refer to a coinciding catalogue of fundamental rights and freedoms" ${ }^{23}$ and in 2006, Constitutional Court of the Russian Federation pointed out in its Resolution that the subject of its regulation, as well as that of the ECtHR, was one and the same, namely - human rights and fundamental freedoms.

However, every year is witnessing a growing number of ECtHR rulings that artificially precipitated collisions between statutes in Russia's Constitution and the Convention. As a result, the ECtHR is factually demanding chat Russia must change its Constitution - a demand that is unconditionally groundless from the legal point of view. ${ }^{24}$

${ }_{21}$ Council of Europe, European Convention for the Protection of Human Rights and Fundamental Freedoms, as amended by Protocols Nos. 11 and 14, 4 November 1950, ETS 5.

22 For the detail in respect of interaction of national legal order and the ECtHR see among many other sources: Frank Emmert, "The Implementation of the European Convention on Human Rights and Fundamental Freedoms in New Member States of the Council of Europe - Conclusions Drawn and Lessons Learned" (Paper at Indiana University Robert H. Mc.Kinney School of Law, December 2011), Frank Emmert and Leonard Hammer, The European Convention on Human Rights and Fundamental Freedoms in Central and Eastern Europe (The Hague: Eleven International Publishing, 2012); Oreste Pollicino and Oleg Soldatov, "Striking the Balance between Human Rights Online and State Security Concerns: The Russian Way in a Comparative Context," German Law Journal 19, no. 1 (2018); Alec Stone Swet and Helen Keller, Assessing the Impact of the ECHR on National Legal Systems (Oxford Scholarship Online, 2008).

23 Valery Zorkin, "The dialogue of the Constitutional Court of the Russian Federation and the European Court on Human Rights in the context of constitutional order." ksrf.ru>News/Speech/Pages/Viewltem.aspx.

24 For the details see Marianna Abramova, "Constitutional Justice of Russia within the judicial landscape of contemporary Europe," Number 40 (2018): 21-44. 
Nevertheless, the positions of the Constitutional Court of the Russian Federation and the European Court of Human Rights regarding private property rights have many points of contact.

First of all, it should be noted that the positions of the courts are close on the issue of which specific rights fall under the guarantee of property rights. The European Court of Human Rights has repeatedly pointed out that the concept of "property" within the meaning of Article 1 of Protocol No. 1 to the Convention has an autonomous meaning that does not boil down to the right of ownership of things and does not depend on a formal classification under national law; some other property rights and interests may be protected under this article (for example Beyeler v. Italy ([GC], number 33202/96, § 100, ECHR 2000-I)).

The Constitutional Court of the Russian Federation also adheres to a broad understanding of property when it comes to constitutional guarantees. In particular, the Constitutional Court of the Russian Federation noted that the concept of "property" used in Article 35 of the Constitution of the Russian Federation in its constitutional sense covers both property rights and claim rights (Judgement of 15 February 2016 No. 3-P). Such rights include, for example, the rights of claim and the legitimate interests of creditors in bankruptcy proceedings (Judgement of 16 May 2000 No. 8-P), as well as property claims of shareholders with protection of the rights of shareholders, including minority shareholders as a weak side in the system of corporate relations (Judgement of 10 April 2003 No. 5-P).

Developing the aforementioned position on the concept of property, the European Court developed the concept of "legal expectation". Although Article 1 of Protocol No. 1 to the Convention applies to property owned by a person and does not confer him the right to receive property, in certain circumstances the "legal expectation" of receiving the property may also be protected. In the case of Béláné Nagy v. Hungary ([GC], number 53080/13, ECHR 2016, § 74-75), the Court stated that such an expectation should be more definite than just hope, and should be based on a rule of law or on a legal act, such as a court 
decision (judgement). The applicant was granted a disability pension in the aforementioned case, which was later cancelled.

The ECtHR found that the refusal to pay money in 2012 caused the applicant an unnecessary burden. According to the Court's position, the applicant, starting from 2001, had "legitimate expectations for a disability pension and when her medical condition required it", therefore these expectations were regarded by the European Court as "property", which falls under the protection of the Article 1 of the First Additional Protocol (the protection of property). It was noted that "if the payment established by the legislation in force at that time, as well as by contributions made to the pension fund, may, under certain conditions, give rise to a right of ownership" ( $(36)$, as well as "in cases where there is a certain right in accordance with national legislation to receive social benefits, the importance of such a right must be confirmed by the application of Article 1 of Protocol No. 1" ( $\$ 37$ ). The Court, in the light of the circumstances of the case, has found a violation of Article 1 of Protocol No. 1 to the Convention.

The concept of legal expectations is also found in the practice of the Constitutional Court of the Russian Federation. For example, the CC RF drew attention to the existence of grounds for legitimate expectations of a reduction in heating fees when equipped with individual meters for living quarters in an apartment building, also equipped with a common house meter (Judgement No. 30-P of 10 July 2018). Legislation that did not allow the testimony of individual metering devices to be taken into account if their safety in separate rooms was not ensured was found to be contrary to the Constitution of the Russian Federation, in particular its Article 35.

Also of interest is the proximity of the approaches of the European Court of Human Rights and the Constitutional Court of the Russian Federation on issues related to confiscation of property - the measure, also being, according to the terminology of the European Court of Human Rights, an interference with the right of ownership guaranteed by Article 1 of the Additional Protocol No. 1. The Court's Judgment in Frizen v. Russia (number 58254/oo, 24 March 2005) concluded that the confiscation of the property of the owner in criminal 
cases brought against his wife must be justified, necessary and based on the law. Since these conditions were not fulfilled in the present case, the European Court found a violation of Article 1 of Protocol 1. The Constitutional Court of the Russian Federation took a similar position, recognizing in its Judgement of 25 April 2011 No. 6-P that the provisions of the law contradict the Constitution of the Russian Federation when allowing sanctioning administrative offenses to confiscate an offense instrument belonging to another person who did not commit unlawful acts with its use. The Constitutional Court of the Russian Federation noted that this situation actually means the application of a measure of responsibility to a person who is not guilty of an administrative offense, and therefore does not correspond to the provisions of Article 35 (Sections 1-3) of the Constitution guaranteeing the right to private property.

Courts have similar positions with regard to the amount of penalties. The ECtHR Judgment in the case of Mamidakis v. Greece (number 35533/04, 11 January 2007) established that a financial liability arising from the payment of a fine if it places an undue burden on the person concerned or it has a significant impact on his financial condition, may cast doubt on this right, guaranteed by the first paragraph of the same Article. The Constitutional Court of the Russian Federation referred to this decision when it reviewed constitutionality of the provisions of the Code of the Russian Federation for Administrative Offenses. In the Judgement of 17 January 2013 No. 1-P the Constitutional Court of the Russian Federation noted that the provisions of the law which, by establishing a significant minimum administrative fine, do not allow a fine to be imposed below the minimum limit, which contradicts to Article 35 (Sections 1- 3 ) of the Constitution and this do not allow, among other things, to take into account the property status of the offender.

And last thing to be discussed in this section is the approaches of the European Court of Human Rights and the Constitutional Court of the Russian Federation to the issue of protecting property rights in respect of one of the most widely discussed cases - the Yukos case. In the Judgment in the case $O A O$ Neftyanaya Kompaniya Yukos v. Russia (number 14902/04, 20 September 2011) 
[Former First Section]), the European Court of Human Rights found inter alia a violation of Article 1 of the First Additional Protocol to the Convention by looking at circumstances of the case outside its national context, which ultimately led to the adoption of the Judgement of the Constitutional Court of the Russian Federation of 19 January 2017 No. 1-P. In the said Judgement the Constitutional Court of the Russian Federation, referring to the problem of alleged violation of the ownership rights of shareholders, noted in paragraph 7 of the Judgement that Russian law does not exclude the possibility of protecting their rights violated by the management of the company. In this regard, in particular, the Government of the Russian Federation is authorized to initiate consideration of the issue of payment of the corresponding amounts in the procedure for the distribution of the newly discovered property of a liquidated legal entity provided for by Russian and foreign legislation, which can only be done after settlements with creditors and taking measures to identify other property (for example hidden in foreign accounts). However, such a payment - based on the legal positions expressed in this Judgement - in any case should not affect budget revenues and expenses, as well as property of the Russian Federation.

In this sense, the Constitutional Court once again emphasised the recognition and real existence in the Russian legal field of the possibilities of protecting property rights.

It is also important that the Constitutional Court of the Russian Federation, in contrast to the approach of the ECtHR, identifies the constitutional and legal meaning of Article 113 of the Tax Code of the Russian Federation, as follows from the legal positions formulated in the Judgement of 14 July 2005 No. 9-P, where the CC RF specified the requirements of Article 57 of the Constitution of the Russian Federation according to their meaning in a systemic connection with other basic constitutional provisions on rights and freedoms that have direct effect. Based on the taxpayers reference to the fact that they could not have foreseen which interpretation of this article the Constitutional Court of the Russian Federation would undertake, in essence, would mean upholding an unconstitutional interpretation of its provisions based on a purely formal 
understanding of the statute of limitations for tax liability offenses, contrary to its actual constitutional legal meaning. Such kind of links are actually used to justify the admissibility of dishonest behaviour of a taxpayer, which was aimed at concealing arrears both in the course of tax control measures and in the audited taxation period as a whole.

Thus, the Constitutional Court of the Russian Federation turned to a comprehensive analysis of the national legal provisions raised in this case, which was not done by the ECtHR in its Judgment (the full English translation of the Judgement of the Constitutional Court can be found on the official webpage of the CC RF).

A time analysis of the legal positions of the Constitutional Court devoted to the right of the private property allows us to conclude that this institution in Russia is now fully established, the exercise of property rights is guaranteed at the European level. Possible restrictions by federal law of the right to own, use and dispose of property, based on the general principles of law, must meet the requirements of justice, be adequate, proportional and necessary to protect constitutionally significant values, including private and public rights and the legitimate interests of others. The state should not arbitrarily interfere in the activities of participants of market transfers.

\section{IV.PROTECTION OF THE RIGHT TO PENSION PROVISION IN THE CASE LAW OF THE CONSTITUTIONAL COURT OF THE RUSSIAN FEDERATION}

The dissolution of the USSR had a great effect on the social sphere, primarily in the sense of political ideology. The emphasis with the purely paternalistic role of the state for all was shifted to the personal development of the majority and the protection of the most vulnerable minority. It follows from the Russian Constitutional Court practice and doctrine that such shift should be done delicately, giving the citizens sufficient period of time to adapt to the changes.

The Constitution of the Russian Federation in accordance with the goals of the social state (Article 7 , Section 1) guarantees everyone social security by 
age, in case of illness, disability, loss of a bread-winner, for raising children and in other cases established by law (Article 39, Section 1). The most important element of social security, the main content of the provision of a person's livelihood, is pension provision. State pensions in accordance with Article 39 (Section 2) of the Constitution of the Russian Federation are established by law.

Reforms of the pension system have occurred quite often in the history of modern Russia due to various reasons, and the Constitutional Court of the Russian Federation has always acted as a guarantor of a certain level of protection of citizens in this matter while distancing itself from interference in the sphere of material and financial capabilities of the state.

As the Constitutional Court of the Russian Federation itself indicated in its Decision of 20 November 1998 No. 176-O, it cannot establish specific amounts of pensions, allowances, types of benefits, etc., since such would mean an assessment of the appropriateness and economic feasibility of decisions of the legislator, which does not belong to the powers of the Constitutional Court.

In general, the main positions from which the Constitutional Court of the Russian Federation proceeds when resolving cases related to pension disputes are: the need to ensure equal conditions for the realization of acquired social rights (Judgement of 3 June 2004 No. 11-P), the inadmissibility of unjustified differentiation in the conditions and norms of social security (Judgement of 25 December 2007 No. 14-P), the inadmissibility of lowering the level of pension provision for citizens (Judgement of 25 December 2007 No. 14-P) and the inadmissibility of significant imbalances between payments for compulsory social insurance and provided insurance coverage (Judgement of 22 March 2007 No. 9-P).

Now I would like to consider in a detail some of the CC RF positions in the field, as well as a number of significant cases of the Constitutional Court of the Russian Federation in this area.

Regarding the early decisions of the Constitutional Court of the Russian Federation, one can note the Judgement of 16 October 1995 No. 11-P, where 
the suspension of the payment of pensions to persons while in prison was recognized as a restriction on the right to social security.

The Constitutional Court of the Russian Federation indicated that retirement pensions are granted in connection with labour or other activities that the legislator recognizes as socially useful. Working citizens, including those in places of deprivation of liberty, through a system of compulsory insurance contributions to the Pension Fund of the Russian Federation participate in the formation of funds for the payment of labour pensions. Thus, these pensions are earned, deserved by previous work, service, and fulfilment of certain duties significant for society.

In the Judgement of 15 June 1998 No. 18-P the Constitutional Court recognized provisions of the Law of the Russian Federation "On the Payment of Pensions to Citizens Going for Permanent Residency outside the Russian Federation" as not complying with the Constitution of the Russian Federation to the extent that they allow depriving pensioners of the right to receive their retirement pensions if they went abroad for permanent residence before 1 July 1993, or after that date, but did not leave immediately before traveling to the territory of the Russian Federation, having established discrimination on ground of nationality and the uncertainty of their normative content.

In the Decision of 21 December 2000 No. 276-O the Constitutional Court of the Russian Federation indicated that, having established for men and women a different age for retirement and the necessary length of service for an old-age pension on general terms and on favourable terms, the legislator applied differentiation, based on physiological and other differences between them, as well as on the basis of the special social role of women in the society related to motherhood, which is consistent with the provision of Article 38 (Section 1) of the Constitution of the Russian Federation, in accordance with which the motherhood is protected by the state and cannot be viewed as a discriminatory restriction of constitutional rights, since such a decision of the legislator provides - in accordance with Article 19 of the Constitution of the Russian Federation - the achievement of a genuine rather than formal equality. 
This does not preclude a possibility in future, during the implementation of the pension reform, to resolve the issue of whether retirement pension should be awarded to men on the same conditions as to women.

The most important decision in the pension sphere is the Judgement of the Constitutional Court of the Russian Federation of 29 January 2004 No. 2-P where the Court established that determining the legal grounds, conditions of appointment, the procedure for calculating pensions and their sizes, the legislator is based on the economic possibilities of society on this stage of its development - should strive to gradually increase the level of pension provision, primarily for those with pensions below the subsistence level, in order to satisfy their basic necessities of life. Moreover, the previously established social security measures for pensioners cannot be cancelled without an equivalent replacement.

In the Judgement of 10 July 2007 No. 9-P, the Constitutional Court of the Russian Federation protected the rights of insured persons in case of nonpayment or incomplete payment by the employer of insurance contributions to the Pension Fund of the Russian Federation.

The federal legislator, carrying out the legal regulation of relations in the field of compulsory pension insurance, must ensure a balance of constitutionally significant interests of all subjects of these relations, and the rules established by him to maintain the stability and autonomy of the financial system of compulsory pension insurance should not invalidate the constitutional right of citizens to retirement pensions.

Failure to pay the insurance contributions to the Pension Fund of the Russian Federation in full for the insured persons working under the employment contract due to the nature and purpose of the compulsory pension insurance and the need to ensure the rights of these persons should not impede the exercise of their rights in a timely manner and receive a retirement pension in full. Corresponding contributions must be paid, and their payment - based on the public law nature of the relationship between the state and the Pension Fund of the Russian Federation and the characteristics of the relationship between the state, policyholders and insured persons - must be provided, including by way 
of enforcement. Otherwise, the essence of the state's obligation to guarantee the right of insured persons to a retirement pension would be distorted.

The challenged laws were found to be inconsistent with the Constitution of the Russian Federation to the extent that in case of non-payment or incomplete payment the insurer (employer) of insurance premiums for certain periods of labour activity of these persons - they allow not to include such periods in their insurance period taken into account when determining the right to a retirement pension, and to reduce the size of its insurance part when assigning (recalculating) a retirement pension. In addition, it happens in the absence of sufficient guarantees for the unhindered exercise of the pension rights of insured persons who worked under an employment contract and who fulfilled the legal conditions for acquiring the right to a retirement pension.

The Judgement of 26 January 2018 No. 10-P reviewed constitutionality of laws, on the basis of which the issue of recovering from a citizen recognized as a disabled person, the amounts of disability pension received and the monthly payment of money in the case when the certificates are submitted to receive appropriate social protection measures, compiled on the basis of medical and social examination, were declared invalid due to procedural violations committed during such an examination.

By virtue of the legal position repeatedly expressed by the Constitutional Court of the Russian Federation, the Constitution of the Russian Federation obliges the state to protect dignity of the individual as a necessary prerequisite and basis for all other inalienable human rights and freedoms, the condition for their recognition and respect, and nothing can be the basis for diminishing individual dignity. In the field of pension provisions, this presupposes, in particular, the establishment of such legal regulation, which - in accordance with the related provisions of Articles 1 (Section 1), 2, 17 (Section 1), 18, 19 (Section 1) and 55 (Sections 2 and 3) of the Constitution of the Russian Federation, with the principles of legal certainty and maintaining the trust of citizens in the law and actions of the state, would guarantee citizens that decisions on the appointment of a pension are made by the authorised state bodies on the 
basis of strict implementation of legislative requirements, as well as careful and a responsible approach to assessing the factual circumstances with which the law connects the emergence of the right to a pension, thoroughness in preparing documents confirming the existence of conditions necessary for assigning a pension and determining its size so that a citizen as a participant in the relevant legal relations can be confident in his officially recognized status and that the rights acquired by virtue of this status will be respected by the state and will be implemented (Judgement of 14 January 2016 No. 1-P; Decision of 7 December 2017 No. 2794-O et al.).

The Constitutional Court of the Russian Federation noted that although a citizen's receipt of the indicated amounts in the absence of legal grounds for it or in an amount greater than what is due under the law falls under the signs of unjust enrichment at the expense of the Pension Fund of the Russian Federation, it should be borne in mind that the citizen is obligated to return the received amounts from the moment the relevant decision is made, the funds due to the identification of only formal (procedural) violations of the procedure for recognising a citizen as a disabled person, another institution of medical and social expertise - in the absence of established facts of bad faith (illegality) on the side of the person concerned - would lead to a disruption of the balance of public and private interest in the pension sector.

In accordance with the revealed constitutional and legal meaning, it is recognized that the contested provisions cannot serve as a basis for recovery from a citizen recognized as a disabled person of the disability pension received and monthly cash payment in that case.

And finally, I would like to dwell on one of the latest decisions of the Constitutional Court of the Russian Federation, which received the greatest public response.

\section{4bis. Pension Reform in Russian Federation}

The pension reform currently underway in Russian, in particular, provides for an increase of age from 60 to 65 years for men and from 55 to 60 years for women, upon reaching which a retirement insurance pension is awarded on a 
common basis; a five-year increase in the age for assigning a social retirement pension to citizens who are not eligible for an insurance pension, as well as the age required for the early appointment of an old-age insurance pension to citizens who work in the Far North and equivalent areas.

The said norms on raising the retirement age became the reason for numerous protests and public demonstrations, as well as the subject of application of a group of deputies of the State Duma of the Federal Assembly of the Russian Federation who addressed the Constitutional Court of the Russian Federation.

In accordance with the applicants' position, the challenged provisions "boil down to the fact that the norms on raising the age are unreasonably introduced, upon reaching which social and insurance pensions will be awarded, which worsens and diminishes the constitutional rights of citizens to social security in old age," and the law itself "as published contrary to the opinion of the majority of citizens and does not meet generally accepted criteria of a social state, as it does not contribute to a decent life and free development of Russian citizens.

In its Inadmissibility Decision of 2 April 2019 No. 854-O, the Constitutional Court of the Russian Federation noted the following:

The choice of organisational and legal forms and mechanisms for the implementation of the constitutional right to pension provision falls within the competence of the legislator, who has a fairly wide margin of appreciation in determining the types of pensions, legal grounds and the procedure for their provision, rules for the appointment and allocation, as well as the formation of the financial basis for their payment. In the exercise of the authority in this area, the legislator has the right not only to establish but also to change the conditions of pension provision, while observing the requirements of the Constitution of the Russian Federation, including its Articles 17 (Section 1), 19 (Sections 1 and 2), 39 (Sections 1 and 2) and 55 (Sections 2 and 3).

Within the meaning of Articles 7, 15 (Section 4), 39, 55 (Section 3), 71 (paragraphs "a" and "c") and 72 (paragraph "g" of part 1) of the Constitution of the Russian Federation in conjunction with relevant international legal documents, 
the legislator is authorised to increase the retirement age, if such an increase is due to socio-economic, demographic, biomedical and other objective factors.

Raising the retirement age - by virtue of Articles 19 (Sections 1 and 2), 39 (Sections 1 and 2) and 55 (Sections 2 and 3) of the Constitution of the Russian Federation - should not lead to abolition or derogation of the constitutional right to social security by age, protected by the constitutional principles of equality and justice. The Constitutional Court of the Russian Federation did not reveal violations of these principles.

The decision also noted compliance with the principle of maintaining citizens' trust in the law and actions of the state, since the new legislation provides for a phased reform, the existence of a transition period to adapt to the amendments, as well as additional guarantees for working citizens of preretirement age.

The Constitutional Court of the Russian Federation once again emphasized that it solves exclusively legal issues and does not consider the contested normative provisions for socio-economic, political and other expediency, including the impact on the socio-economic and political situation, as well as from economic feasibility (Judgements of the Constitutional Court of the Russian Federation of 11 November 1997 No. 16-P, 22 July 2002 No. 14-P, 9 July 2012 No. 17-P, 19 March 2014 No. 6-P, and 6 December 2018 No. 44-P; Decisions of the Constitutional Court of the Russian Federation of 12 July 2001 No. 179-O, 2 October 2003 No. 382-O, etc.).

Thus, it was established that the contested provisions do not contain uncertainty regarding the compliance with the Constitution of the Russian Federation, since it does not exclude the possibility of augmenting the retirement age by a federal law. The question of the appropriateness of this measure cannot be resolved by the Constitutional Court of the Russian Federation; otherwise, the Court would go beyond its competence, the request was deemed not raise grounds for further consideration.

This decision was criticized by the political opposition, as well as by a fairly broad mass of the population, however, considering it in the context of 
the study, the fidelity of the Constitutional Court of the Russian Federation to its previous legal positions and the principle of reasonable constitutional and legal restraint and non-interference in the discretion of the legislator, which is recognized as unconditional the right to make political decisions, and therefore the principle of separation of powers and the foundations of the constitutional system of the Russian Federation.

\section{CONCLUSION}

As I noted, the problem of the extent of judicial intervention in the sphere of realisation of socio-economic rights shall be considered from the point of view of admissibility, degree and possibility of the influence on democratically elected bodies from the side constitutional justice.

The decisions cited earlier and the legal positions of the Constitutional Court of the Russian Federation illustrates the conclusion on the general role of the Constitutional Court of the Russian Federation in protecting the socio-economic rights of citizens both from a historical perspective and at the present stage of development of Russia. As N.S. Bondar noted back in 2003, the social policy of today's democratic Russia declares two main tasks: firstly, to protect the most vulnerable parts of the population from the harsh impact of the emerging market; secondly, to promote the economic activation of various segments of the population and, on this basis, contribute to the liberation of the state from the function of the direct "guardian" of its citizens, to overcome the Soviet legacy of state paternalism in the social sphere. ${ }^{25}$ After 15 years, we can say that these tasks are still relevant. Therefore, often when resolving cases in the socio-economic sphere, the role of the Constitutional Court of the Russian Federation is to find a very delicate balance between the interests of various social groups and the interests of the state, between the possibilities for personal development and the right to state support and, more broadly, between two concepts - a social and legal democratic state, proclaimed by the Constitution of the Russian Federation.

25 Bondar, "Zashchita sotsial'no-ekonomicheskikh," 161. 
The present analysis of the legal positions of the Constitutional Court of the Russian Federation in the socio-economic sphere allows us to conclude also that: 1. The Constitutional Court may interpret the provisions of the Constitution taking into account the specific historical situation and make a dynamic correction of its legal positions.

2. The Constitutional Court develops a doctrine of constitutional self-restraint to prevent the potential encroachment of the Court on the powers of the executive or legislator. This doctrine allows to opt for more general instructions given remain final and obligatory.

In such a context, one can compare the Constitutional Court of the Russian Federation with a chess player. As a chess player, the Constitutional Court moves its pawns on the chessboard of the Russian state. The task of this party is to uphold the rule of law. And victory is not the only aim in this process of building a state governed by law, it is also important to suppress any attack thereon. The Constitutional Court of Russia, to continue the chess metaphor, is not blocked in this game. After a stormy beginning and difficult times (the formation of the new Russian state), the Constitutional Court of the Russian Federation today finds opportunities and can count on winning combinations, even if it is restricted with the constitutional system of checks and balances. ${ }^{26}$

\section{BIBLIOGRAPHY}

Abramova, Marianna. "Constitutional Justice of Russia within the judicial landscape of contemporary Europe." Revista Derecho del Estado, no. 40 (2018). https://dx.doi.org/10.18601/01229893.n40.02.

Alston, Philip and Gerard Quinn. "The Nature and Scope of States Parties' Obligations under the International Covenant on Economic, Social and Cultural Rights." Human Rights Quarterly 9, no.2 (May, 1987). https://www. jstor.org'stable/762295?seq=1.

${ }_{26}$ Marie-Elisabeth Baudoin, "La Cour constitutionnelle de la Fédération de Russie vue par un juriste français [The Constitutional Court of the Russian Federation seen by a french lawer]," Cahiers du Conseil constitutionnel [Notebooks of the Constitutional Council] no. 28, July, 2010. 
Baudoin, Marie-Elisabeth. "La Cour constitutionnelle de la Fédération de Russie vue par un juriste français [The Constitutional Court of the Russian Federation seen by a french lawer]." Cahiers du Conseil constitutionnel [Notebooks of the Constitutional Council] no. 28. July, 2010. https://www. conseil-constitutionnel.fr/nouveaux-cahiers-du-conseil-constitutionnel/lacour-constitutionnelle-de-la-federation-de-russie-vue-par-un-juriste-francais.

Bondar, Nikolai. “Zashchita sotsial'no-ekonomicheskikh prav konstitutsionnymi sudami stran Vostochnoy Yevropy. Rossiyskaya Federatsiya. Konstitutsionnoye pravosudiye i sotsial'noye gosudarstvo [Protection of Socio-Economic Rights by the Constitutional Courts of Eastern Europe. Russian Federation. Constitutional Justice and Welfare State].” M. Institut prava i publichnoy politiki, 2003.

Constitution of the Russian Federation. "Constitution of the Russian Federation - 1993." http://www.ksrf.ru/en/INFO/LEGALBASES/CONSTITUTIONRF/ Pages/default.aspx.

Constitutional Court of the Russian Federation. "Federal Constitutional Law of July 21, 1994, No. 1-FCL.” http://www.ksrf.ru/en/Info/LegalBases/FCL/ Pages/default.aspx.

Danelciuc-Colodrovschi, Natasa. "Fédération de Russie [Russian Federation]". Annuaire international de justice constitutionnelle [The international yearbook of the constitutional justice], 2014. https://doi.org/10.3406/ aijc.2014.2178.

Desierto, Diane A. "Justiciability of Socio-Economic Rights: Comparative Powers, Roles, and Practices in the Philippines and South Africa." Asian-Pacific Law E Policy Journal 11, no. 1 (2009).

Emmert, Frank. "The Implementation of the European Convention on Human Rights and Fundamental Freedoms in New Member States of the Council of Europe - Conclusions Drawn and Lessons Learned." Paper at Indiana University Robert H. Mc.Kinney School of Law, December 2011. 
Emmmert, Frank and Lenonard Hammer. The European Convention on human rights and fundamental freedoms in Central and Eastern Europe. The Hague: Eleven International Publishing, 2012.

International Commission of Jurists. "Courts and the Legal Enforcement of Economic, Social and Cultural Rights: Comparative Experiences of Justiciability." Geneva, 2008. https://www.escr-net.org/docs/i/1143054.

Kleinlein, Thomas. "The Procedural Approach in International Human Rights Law and Fundamental Values: Towards a Proceduralization of the Interface of International and Domestic Law." European Society of International Law (ESIL) 2017, Annual Conference (Naples), April 15, 2018.

Kolotova, Natalya. "Konstitutsionalizatsiya sotsial'nykh prav - tendentsiya razvitiya sovremennogo prava [Constitutionalization of Social Rights - a Trend in the Development of Modern Law]." Konstitutsionnoye i munitsipal'noye pravo [Constitutional and Municipal Law], no.1 (2019).

Kuznetcov, Dmitrii. "Sudebnaya zashchita sotsial'no-ekonomicheskikh prav: Pro et Contra [Justiciability of Social and Economic Rights: Pro et Contra]." Vremya I Pravo [Time and Law], no. 4 (2014).

Liebenberg, Sandra. Social and Economic Rights in Constitutional Law of South Africa 41-11 (M. Chaskalson et al (eds.)). Cape Town: Juta, 1996.

Mesquita, Ceia Eleonora. "The applicability of the political question doctrine in the foreign affairs field: should international treaties be regarded as non-justiciable acts?" Paper presented at the IACL 2007 World Congress, Athens, June 2007.

Nolan, Aoife, Bruce Porter, Malcolm Langford. "The Justiciability of Social and economic Rights: an Updated Appraisal." CHRGJ Working Paper No. 15, 2007.

Official Website of the Constitutional Court of the Russian Federation. "About the Court." http://www.ksrf.ru/EN/INFO/Pages/default.aspx. 
Pollicino, Oreste and Oleg Soldatov. "Striking the Balance between Human Rights Online and State Security Concerns: The Russian Way in a Comparative Context." German Law Journal 19, no. 1 (2018).

Popova, Arina V. "A Guide to Legal Research in Russia (update version)." A peper from Haser Global Law School Program. https://www.nyulawglobal. org/globalex/Russia_Legal_Researchı.html.

Shue, Henry. Chapters 1-2 of Basic Rights: Subsistence, Affluence, and U.S. Foreign Policy. Princeton University Press, 1980.

Sweet, Alec Stone and Helen Keller. Assessing the Impact of the ECHR on National Legal Systems. Oxford Scholarship Online, 2008.

Zorkin, Valery. "Rossiya: dvizheniye k pravu ili khaosu. Sotsial'no-gosudarstvennyy krizis i pravovaya sistema [Russia: Movement towards Law or Chaos. Social and State Crisis and Legal System]." URL: /http://www.patriarchia.ru/db/ text/209611.html.

Zorkin, Valery. "Pretsedentnyy kharakter resheniy Konstitutsionnogo Suda Rossiyskoy Federatsii [The Precedent Nature of Decisions of the Constitutional Court of the Russian Federation].” Zhurnal konstitutsionnogo prava. no. 12 (2004).

Zorkin, Valery. "Sotsial'noye gosudarstvo v Rossii: problemy sotsializatsii [The Social State in Russia: Problems of Socialization].” Sravnitel'noye konstitutsionnoye obozreniye [Comparative Constitutional Review], no. 1 (2008).

Zorkin, Valery. Axiological Aspects of the Russian Constitution. Chapter in Constitutional Topography Vol.6. Eleven International Publishing. 2010.

Zorkin, Valery. "Dialog Konstitutsionnogo Suda Rossiyskoy Federatsii I Evropeiskogo Suda po pravam tcheloveka v kontexte konstitutsionnogo pravoporiadka [The dialogue of the Constitutional Court of the Russian Federation and the European Court on Human Rights in the context of constitutional order]." http://ksrf.ru>News/Speech/Pages/ViewItem.aspx. 